\title{
Effects of $\mathrm{CaF}_{2}$ Addition on the Structure of $\mathrm{CaO}-\mathrm{Al}_{2} \mathrm{O}_{3}-\mathrm{SiO}_{2}$ Glasses
}

\author{
Tomoaki MAEDA, Shigeki MATSUYA and Michio OHTA \\ Department of Dental Materials Engineering \\ Faculty of Dentistry, Kyushu University \\ 3-1-1 Maidashi, Higashi-ku, \\ Fukuoka 812-8582, Japan
}

Received January 15, 1998/Accepted March 5, 1998

\begin{abstract}
XPS and NMR analyses were done on the $\mathrm{CaO}-\mathrm{Al}_{2} \mathrm{O}_{3}-\mathrm{SiO}_{2}$ and $\mathrm{CaO}-\mathrm{Al}_{2} \mathrm{O}_{3}-\mathrm{SiO}_{2}-\mathrm{CaF}_{2}$ glasses to investigate the effect of fluoride on the glass structure. The XPS spectra showed that most of of the fluoride combined with $\mathrm{Ca}$ and $\mathrm{Al}$ or existed as a free ion in the glasses. The number of $\mathrm{F}$ per $\mathrm{Ca}$ atom and the fraction of free $\mathrm{F}^{-}$ion decreased with increasing $\mathrm{Al} /(\mathrm{Al}+\mathrm{Si})$ ratio in the glasses with $\mathrm{Ca} / \mathrm{Al}=0.5$. The fraction of free $\mathrm{F}^{-}$ion increased at high $\mathrm{CaO}$ content in the glasses containing about $45 \mathrm{~mol} \% \mathrm{SiO}_{2}$. The chemical shift of the fluoride-containing glasses in ${ }^{29} \mathrm{Si}$ NMR spectra was smaller than that of the non-fluoride glasses. The chemical shift of the glasses in ${ }^{27} \mathrm{Al}$ NMR spectra also showed the same tendency as in ${ }^{29} \mathrm{Si}$ NMR spectra. The addition of fluoride caused an increase in the average number of bridging oxygen atoms in the aluminosilicate glass network. However, the average number of $\mathrm{Al}$ around a $\mathrm{SiO}_{4}$ tetrahedron (n) decreased in the species, $\mathrm{Si}-(\mathrm{O}-\mathrm{Si})_{4-n}(\mathrm{O}-\mathrm{Al})_{n}$.
\end{abstract}

Key words: XPS, NMR, Calcium aluminosilicate glass

\section{INTRODUCTION}

The powder in commercial glass-ionomer cements is aluminosilicate glasses containing fluorides and phosphates ${ }^{1}$. The liquid component of the cement is a concentrated solution of polymeric acid, for instance, polyacrylic acid or a copolymer of acrylic and itaconic acids ${ }^{1,2)}$. The liquid also contains tartaric acid to improve the workability of the cement ${ }^{3}$. When the powder and the liquid are mixed, the cement hardens within a few minutes in the oral environment. Fluoride addition to the glass prolongs the working time of the cement ${ }^{4)}$ and results in an anticariogenic property of the cement by fluoride release ${ }^{5}$. Thus the fluoride plays an important role in the clinical use of the cement.

The effect of fluoride addition on the structure of silicate or aluminosilicate glasses has been investigated by many researchers ${ }^{6-9}$. Among those, fluoride behavior in the silicate glasses is classified into three ways; 1 ) acts as a network modifier, 2) exists as a free fluoride ion, 3) combines with modifying cation such as $\mathrm{Ca}^{2+}$ or $\mathrm{Al}^{3+}$ ions. Kumar et $a l^{6}{ }^{6}$ reported that the fluoride behavior varied with the content of modifying oxide in the glass. When the content was less than $55-60 \mathrm{~mol} \%$, fluoride combined with a silicon atom according to the following equation, 


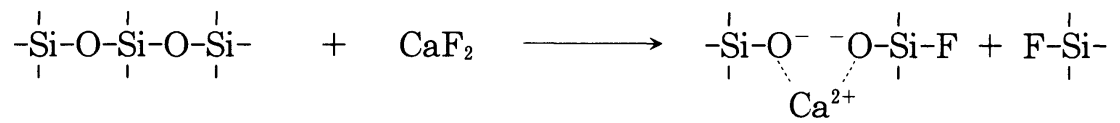

However, with increased oxide content, fluoride existed as a free $\mathrm{F}^{-}$ion. Yamane also revealed the existence of the free $\mathrm{F}^{-}$ion in $\mathrm{SiO}_{2}-\mathrm{CaO}-\mathrm{CaF}_{2}$ glasses based on $\mathrm{X}-$ ray photoelectron spectroscopy (XPS), concluding that the $\mathrm{Si}-\mathrm{F}$ bond did not exist in the glasses. Iwamoto ${ }^{8)}$ reported that fluoride combined with an $\mathrm{Si}$ atom in $\mathrm{SiO}_{2}-$ $\mathrm{CaO}-\mathrm{CaF}_{2}$ glasses containing less than $7 \mathrm{~mol} \%$ of $\mathrm{CaF}_{2}$ and combined with $\mathrm{Ca}$ in glasses containing more than $7 \mathrm{~mol} \%$ of $\mathrm{CaF}_{2}$. On the other hand, there are only a few studies on the effects of fluoride addition on the structure of aluminosilicate glasses. Kohn ${ }^{9)}$ described in their ${ }^{27} \mathrm{Al}$ magic angle spinning nuclear magnetic resonance (MAS NMR) study that four, five and six-coordinated $\mathrm{Al}$ coexisted in $\mathrm{SiO}_{2}$ $\mathrm{Al}_{2} \mathrm{O}_{3}-\mathrm{Na}_{2} \mathrm{O}-\mathrm{NaF}$ glasses and that five-coordinated $\mathrm{Al}$ existed as the $\mathrm{AlF}_{5}{ }^{2-}$ species. It was also reported ${ }^{10,11)}$ that fluoride probably combined with both $\mathrm{Ca}$ and $\mathrm{Si}$ in the glass with a composition of $2 \mathrm{SiO}_{2} \cdot \mathrm{Al}_{2} \mathrm{O}_{3} \cdot 2(1-\mathrm{x}) \mathrm{CaO} \cdot \mathrm{xCaF}_{2}$. Thus, there is still controversy on the fluoride behavior in silicate or aluminosilicate glasses.

In the present study, we investigated the structure of the calcium aluminosilicate glasses and those in which a part of the $\mathrm{CaO}$ was substituted with $\mathrm{CaF}_{2}$. For this purpose, ${ }^{29} \mathrm{Si}$ and ${ }^{27} \mathrm{Al}$ MAS NMR spectroscopy and XPS for F1s were carried out with the glasses. The aim of this study was to elucidate the fluoride behavior in the glasses.

\section{MATERIALS AND METHODS}

\section{Materials}

Four series of the glass samples were prepared by melting the component oxides or fluoride in a $\mathrm{Pt}$ crucible. The analyzed composition of the glasses prepared are plotted on the triangle diagram in Fig. 1. Series I a glasses (L, F, S) had a composition range of 36.0-56.6 mol\% $\mathrm{SiO}_{2}$ with an equimolar ratio of $\mathrm{Al}_{2} \mathrm{O}_{3}$ and $\mathrm{CaO}$. In series I b glasses, the composition was the same as series I a glasses except that a part of the $\mathrm{CaO}$ was replaced by $\mathrm{CaF}_{2}$ (L': $12 \mathrm{~mol} \%$, F': $11.1 \mathrm{~mol} \%$, S': $9.8 \mathrm{~mol} \%$ ). Series II a glasses $(F, X, Y)$ contained about $44 \mathrm{~mol} \% \mathrm{SiO}_{2}$ with $\mathrm{Al}_{2} \mathrm{O}_{3}$ content varying between 13.7 and $28.8 \mathrm{~mol} \%$. In series II b glasses, a part of the $\mathrm{CaO}$ was replaced by $\mathrm{CaF}_{2}$ (X': $11.4 \mathrm{~mol} \%, \mathrm{Y}: 11.0 \mathrm{~mol} \%$ ) in a similar way to series I b. - The $\mathrm{CaF}_{2}$ content of about $11 \mathrm{~mol} \%$ was equivalent to that of $5-6.4 \mathrm{wt} \% \mathrm{~F}$ and was adopted according to the content of 4-9 wt\% $\mathrm{F}$ in the commercial glass ionomer cements. With the glass containing $\mathrm{CaF}_{2}$, the nominal composition differed greatly from the analyzed one, because of the volatilization of fluorine as $\mathrm{SiF}_{4}$. Therefore the composition of the glasses containing fluoride was determined by chemical analysis. Fluoride was analyzed with a fluoride ion electrode attached to an ion meter (Ionalyzer 901, Orion Research, Cambridge, MA, USA). An equal volume of TISABII solution (Total ionic strength adjustor, Orion Research, Cambridge, MA, USA) was added to adjust the $\mathrm{pH}$ and to break the aluminum fluoride complexes before analysis. $\mathrm{Al}$ - and $\mathrm{Ca}$-contents 


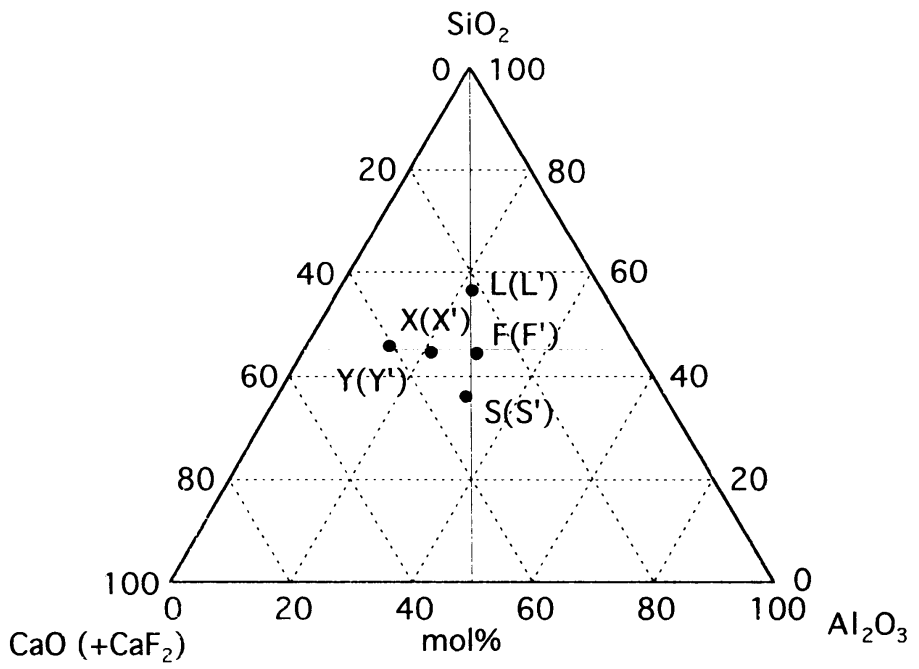

Fig. 1 Composition of the glass samples used in this study. $\mathrm{CaO}-\mathrm{Al}_{2} \mathrm{O}_{3}-\mathrm{SiO}_{2}$ glasses: series $\mathrm{I} \mathrm{a}(\mathrm{L}, \mathrm{F}, \mathrm{S})$; series II $\mathrm{b}(\mathrm{F}, \mathrm{X}, \mathrm{Y})$ $\mathrm{CaO}-\mathrm{Al}_{2} \mathrm{O}_{3}-\mathrm{SiO}_{2}-\mathrm{CaF}_{2}$ glasses: series $\mathrm{I} \mathrm{b}\left(\mathrm{L}^{\prime}, \mathrm{F}^{\prime}, \mathrm{S}^{\prime}\right)$; series II $b\left(F^{\prime}, X^{\prime}, Y^{\prime}\right)$

were determined with an atomic absorption spectrometer (AA630, Shimadzu, Kyoto, Japan).

The glass prepared was ground and passed through a $75 \mu \mathrm{m}$ sieve. The powder sample was used for NMR measurement. For XPS analysis, a surface of the bulk glass with a size of ca. $4 \times 4 \times 3 \mathrm{~mm}^{3}$ was polished with fine alumina powder.

XPS of F1s

F1s XPS spectra of the glasses were obtained by an $\mathrm{X}$ ray photoelectron spectrometer (ESCA750, Shimadzu, Kyoto, Japan) equipped with $\mathrm{MgK} \alpha \mathrm{X}$-ray source operating at $10 \mathrm{kV}$ and $30 \mathrm{~mA}$. The binding energy was corrected with a binding energy of Au4f $7 / 2$ coated on the surface of the glass sample. The surface of the glass sample was etched by an Argon ion beam for $30 \mathrm{~min}$ to eliminate surface contamination before XPS measurement. The XPS spectra was obtained after confirmation that the spectra were unaffected by the Ar ion beam etching.

${ }^{29} \mathrm{Si}$ and ${ }^{27} \mathrm{Al} \mathrm{MAS}$ NMR

${ }^{27} \mathrm{Al}$ and ${ }^{29} \mathrm{Si}$ MAS NMR spectra were taken by an FT-NMR spectrometer (AM400, Bruker, Germany) equipped with a $\mathrm{CP} / \mathrm{MAS}$ unit. The resonance frequencies were 104.3 $\mathrm{MHz}$ for ${ }^{27} \mathrm{Al}$ and $79.5 \mathrm{MHz}$ for ${ }^{29} \mathrm{Si}$. The spinning rate of the sample was $4 \mathrm{kHz}$ unless otherwise noted. References for the chemical shift were $\mathrm{AlCl}_{3} 6 \mathrm{H}_{2} \mathrm{O}$ and tetramethylsilane, and their chemical shifts were set at $0 \mathrm{ppm}$. The repetition time was $0.5 \mathrm{~s}$ for ${ }^{27} \mathrm{Al}$ and $5 \mathrm{~s}$ for ${ }^{29} \mathrm{Si}$, respectively. 


\section{RESULTS AND DISCUSSION}

\section{F1s XPS spectra of the glasses containing fluoride}

Figs. 2 (a) and (b) show F1s XPS spectra of the glasses in series I b (L', F' and S') and those of the glasses in series II b (F', $\mathrm{X}^{\prime}$ and $\left.\mathrm{Y}^{\prime}\right)$, respectively. Each of the glasses showed a single broad peak around $686 \mathrm{eV}$, which changed its position depending on the glass composition. In series I b glasses, the chemical shift of the peak maxima shifted to a slightly higher energy with decreasing the $\mathrm{SiO}_{2}$ content. In series II $\mathrm{b}$ glasses, the glass $\mathrm{Y}$ ' showed a peak maximum at the lowest binding energy. The binding energy of each atom combining with an $\mathrm{F}$ atom is reported to be $687.8 \mathrm{eV}$ (2 $\mathrm{eV})$ for $\mathrm{Si}-\mathrm{F}, 686.5 \mathrm{eV}$ for $\mathrm{Al}-\mathrm{F}$ and $685.3 \mathrm{eV}(2 \mathrm{eV})$ for $\mathrm{Ca}^{-\mathrm{F}^{7}}$. The figures in parentheses show the half width of the peak. The observed peaks appeared in the region of those binding energies (Fig. 2). Yamane et $a l^{{ }^{7)}}$ reported that F1s spectra for $\mathrm{CaO}-\mathrm{SiO}_{2}-\mathrm{CaF}_{2}$ glasses showed a single peak at $684.5 \mathrm{eV}$ with a half width of $2 \mathrm{eV}$.
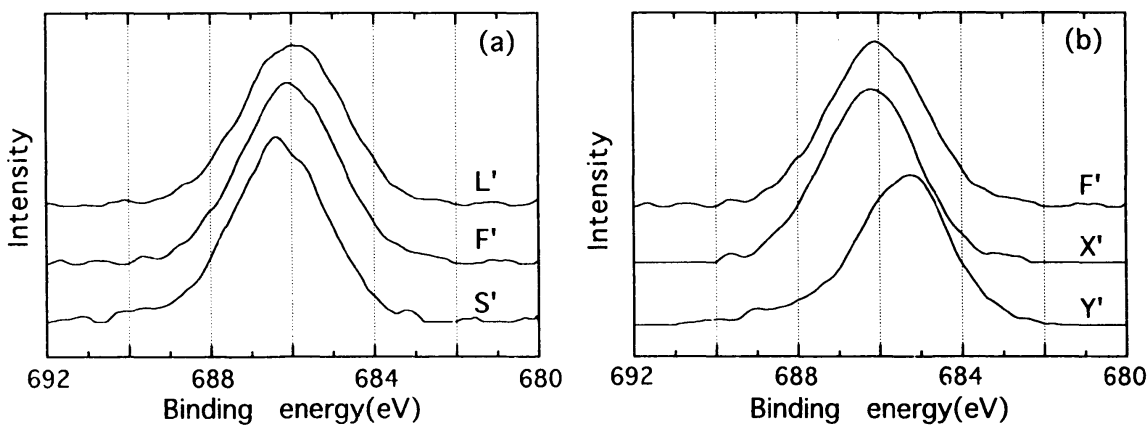

Fig. 2 F1s XPS spectra of the glasses in series $I \mathrm{~b}(\mathrm{a})$ and the glasses in series II $\mathrm{b}(\mathrm{b})$.

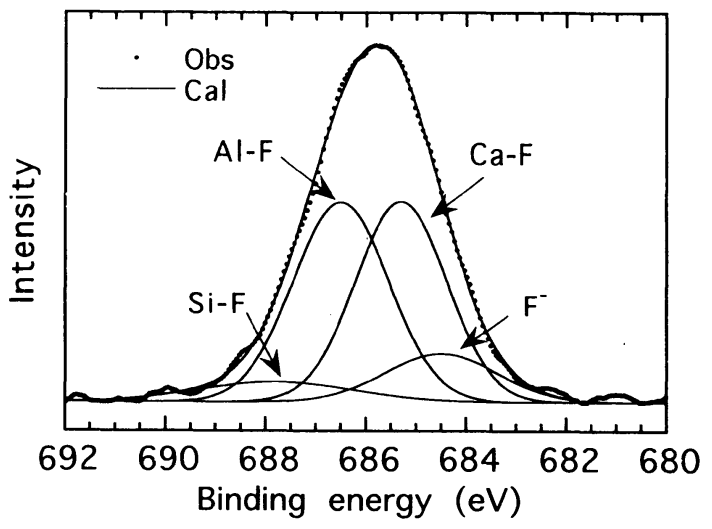

Fig. 3 A typical example of the peak separation for F1s XPS spectra of glass L'. 

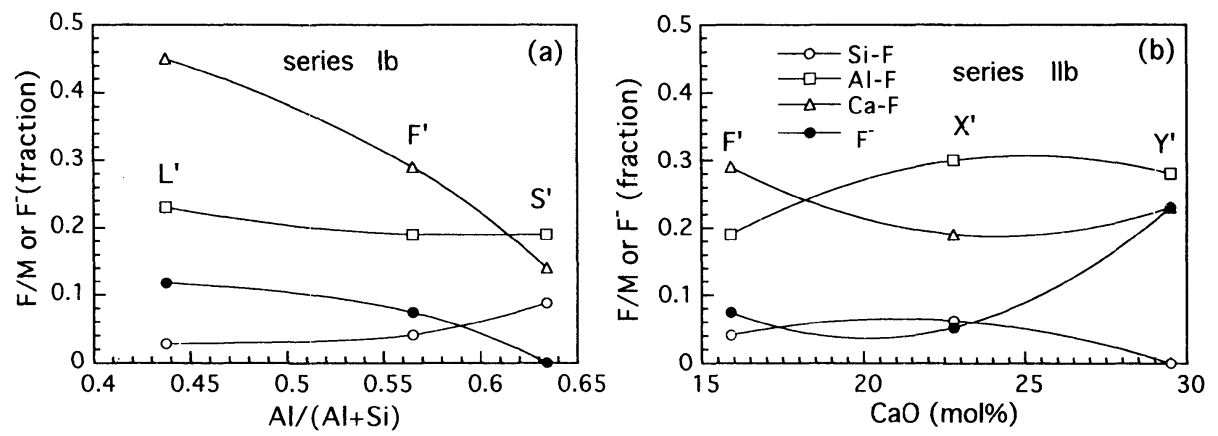

Fig. 4 Change in the number of $\mathrm{F}$ atom per $\mathrm{Si}, \mathrm{Al}$ or $\mathrm{Ca}$ atom and fraction of free $\mathrm{F}^{-}$ion with $\mathrm{Al} /(\mathrm{Al}+\mathrm{Si})$ ratio in series $\mathrm{I} b$ glasses $(\mathrm{a})$ and with $\mathrm{CaO}$ content in series II b glasses (b).

The chemical shift was lower by $0.8 \mathrm{eV}$ than that of the $\mathrm{F} 1 \mathrm{~s}$ peak for $\mathrm{Ca}-\mathrm{F}$ in a crystalline $\mathrm{CaF}_{2}$. They concluded that the $\mathrm{F}^{-}$ion existed as a free ion bonded with no other cations in the $\mathrm{CaO}-\mathrm{SiO}_{2}-\mathrm{CaF}_{2}$ glasses. In the present study, however, the observed $\mathrm{F} 1 \mathrm{~s}$ peak had a higher binding energy $(686 \mathrm{eV})$ than that for the free $\mathrm{F}^{-}$ion in the $\mathrm{CaO}-\mathrm{SiO}_{2}-\mathrm{CaF}_{2}$ glasses. Moreover, the peak widths of $2.5-3 \mathrm{eV}$ were slightly too large to regard those peaks as a single peak. Thus it is suggested that fluorine atoms would bond with $\mathrm{Si}, \mathrm{Al}$ or $\mathrm{Ca}$ atoms or exist as free ions in these glasses. To determine the fraction of each binding state, we attempted peak separation assuming that a peak for the binding state was expressed in a Gaussian form. The peak separation was carried out using a least-square method, changing the peak height and half-width of each separated peak ${ }^{12}$. Fig. 3 shows a typical example of the peak separation for glass L'. The fraction of each bond was determined based on the peak area. To make comparison easy, the number of $\mathrm{F}$ atoms per each atom was calculated from the fraction obtained. Figs. 4 (a) and (b) show the change in the number of $\mathrm{F}$ atom per $\mathrm{Si}, \mathrm{Al}$ and $\mathrm{Ca}$ atoms in the glasses containing fluoride with $\mathrm{Al} /(\mathrm{Al}+\mathrm{Si})$ ratio (series $\mathrm{I} b$ ) and with $\mathrm{CaO}$ content (series $\mathrm{II} \mathrm{b}$ ). The fraction of the free $\mathrm{F}^{-}$ion is also plotted in Fig. 4. In series $\mathrm{I} b$ glasses, it was noted that the number of $\mathrm{F}$ per $\mathrm{Ca}$ atom and the fraction of free $\mathrm{F}^{-}$ion decreased with an increase in $\mathrm{Al} /(\mathrm{Al}+\mathrm{Si})$ ratio. On the other hand, in series II b glasses, the fraction of free $\mathrm{F}^{-}$ion increased at high $\mathrm{CaO}$ content. The number of $\mathrm{F}$ per $\mathrm{Si}$ atom was less than 0.1 and most of the fluoride ions preferentially bond to $\mathrm{Al}$ or $\mathrm{Ca}$ ions in both series of glasses. It was reported ${ }^{7)}$ that $\mathrm{F}^{-}$ion existed as a free ion in the $\mathrm{CaO}-\mathrm{SiO}_{2}-\mathrm{CaF}_{2}$ glasses. Our result does not agree with this description, probably because the $\mathrm{Al}^{3+}$ ion tended to form fluoride or oxyfluoride complexes in the aluminosilicate glasses, as described later.

${ }^{29} \mathrm{Si}$ MAS NMR spectra for the glasses

Fig. 5 shows ${ }^{29} \mathrm{Si}$ MAS NMR spectra for the $\mathrm{CaO}-\mathrm{Al}_{2} \mathrm{O}_{3}-\mathrm{SiO}_{2}$ glasses (L, F, S, X, Y) and the $\mathrm{CaO}-\mathrm{Al}_{2} \mathrm{O}_{3}-\mathrm{SiO}_{2}-\mathrm{CaF}_{2}$ glasses ( $\mathrm{L}^{\prime}, \mathrm{F}^{\prime}, \mathrm{S}^{\prime}, \mathrm{X}^{\prime}, \mathrm{Y}^{\prime}$ ). A broad peak was observed between -70 and $-120 \mathrm{ppm}$ in both of the glasses. Fig. 6 shows the ${ }^{29} \mathrm{Si} \mathrm{NMR}$ chemical 

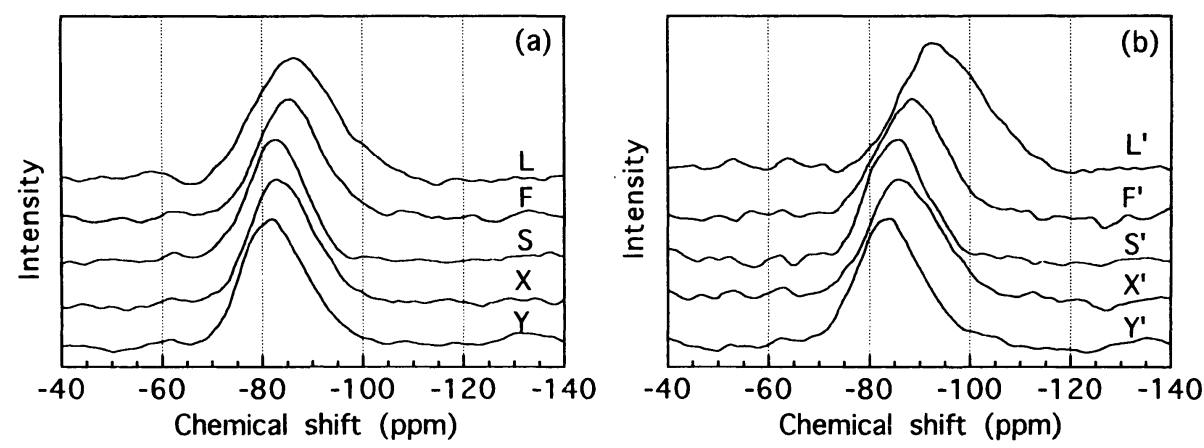

Fig. $5{ }^{29} \mathrm{Si}$ MAS NMR spectra for the $\mathrm{CaO}-\mathrm{Al}_{2} \mathrm{O}_{3}-\mathrm{SiO}_{2}$ glasses (a) and the $\mathrm{CaO}-$ $\mathrm{Al}_{2} \mathrm{O}_{3}-\mathrm{SiO}_{2}-\mathrm{CaF}_{2}$ glasses (b).
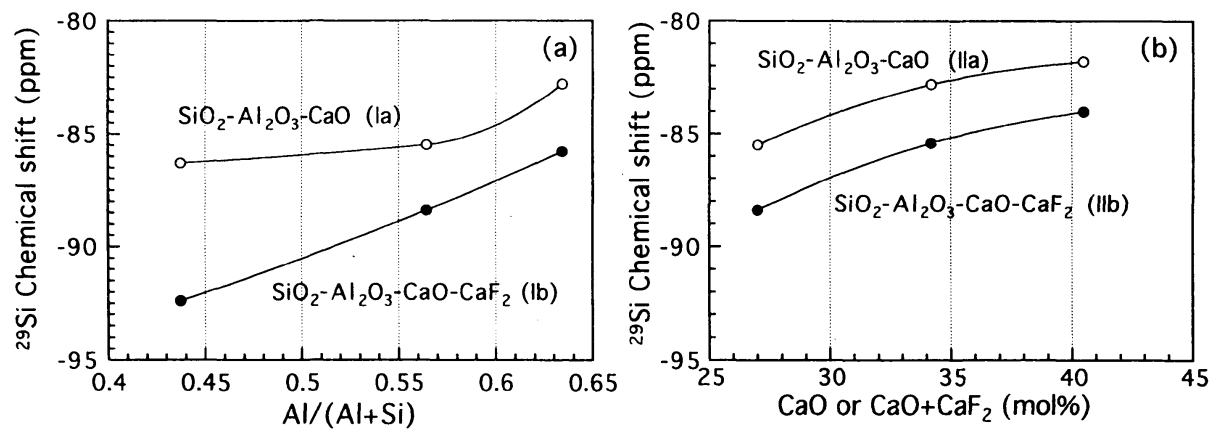

Fig. $6{ }^{29} \mathrm{Si}$ MAS NMR chemical shift of a peak maximum plotted against the $\mathrm{Al} /(\mathrm{Al}+\mathrm{Si})$ ratio in series $\mathrm{I} a$ and $\mathrm{I} \mathrm{b}$ glasses (a) and against $\mathrm{CaO}$ or $\mathrm{CaO}+\mathrm{CaF}_{2}$ content in series II a and II b glasses (b).

shift of a peak maximum plotted against the $\mathrm{Al} /(\mathrm{Al}+\mathrm{Si})$ ratio in series $\mathrm{I}$ a and $\mathrm{I} \mathrm{b}$ glasses (a) and against $\mathrm{CaO}$ or $\mathrm{CaO}+\mathrm{CaF}_{2}$ content in series II a and II b glasses (b). The glasses containing fluoride showed more negative chemical shift compared with those of glasses without fluorides. It was reported ${ }^{13)}$ that the chemical shift of a tetrahedrally-coordinated $\mathrm{Si}$ atom was between -60 and $-130 \mathrm{ppm}$ and that of six-coordinated $\mathrm{Si}$ atom between -190 and $-215 \mathrm{ppm}$. The glasses synthesized in the present study contained only tetrahedrally-coordinated $\mathrm{Si}$ atoms. The structure of calcium aluminosilicate glasses is represented by a network consisting of $\mathrm{SiO}_{4}$ tetrahedra and $\mathrm{AlO}_{4}$ tetrahedra. Connection of both tetrahedra are defined by $\mathrm{Q}^{\mathrm{m}}(\mathrm{nAl})$ species, $\mathrm{Si}$ $(\mathrm{O}-\mathrm{Si})_{\mathrm{m}-\mathrm{n}}(\mathrm{O}-\mathrm{Al})_{\mathrm{n}}\left(\mathrm{O}^{-}\right)_{4-\mathrm{n}}$, where $\mathrm{m}$ is the number of bridging oxygen atoms per $\mathrm{Si}$ atom and $\mathrm{n}$ the number of $\mathrm{Al}$ as nearest neighbors ${ }^{12)}$. It is not known whether ${ }^{29} \mathrm{Si} \mathrm{MAS}$ NMR spectra are altered by the coordination of $\mathrm{F}$ around the $\mathrm{Si}$ atom. However, the $\mathrm{Si}-\mathrm{F}$ bond was not formed much in the glasses used in this study, as shown in the results of XPS (Figs. 4(a) and (b)). Moreover, the environment of $\mathrm{Al}$ next to a $\mathrm{SiO}_{4}$ tetrahedron seemed not to greatly affect the ${ }^{29} \mathrm{Si}$ peak in its NMR spectrum. From 
Table $1 \mathrm{Q}^{\mathrm{m}}(\mathrm{nAl})$ distribution in the glasses calculated from ${ }^{29} \mathrm{Si}$ NMR spectra

\begin{tabular}{ccrrrrrrrrrr}
\hline glass & $\mathrm{Q}^{4}(0 \mathrm{Al})$ & $\mathrm{Q}^{4}(1 \mathrm{Al})$ & $\mathrm{Q}^{4}(2 \mathrm{Al})$ & $\mathrm{Q}^{4}(3 \mathrm{Al})$ & $\mathrm{Q}^{4}(4 \mathrm{Al})$ & $\mathrm{Q}^{3}(1 \mathrm{Al})$ & $\mathrm{Q}^{3}(2 \mathrm{Al})$ & $\mathrm{Q}^{3}(3 \mathrm{Al})$ & Ave.m & Ave.4n & Ave.3n \\
\hline $\mathrm{L}$ & 5.2 & 4.7 & 24.4 & 41.3 & 13.3 & 8.1 & 3.2 & 0.0 & 3.89 & 2.60 & 1.28 \\
$\mathrm{~L}$ & 9.1 & 12.0 & 38.1 & 27.8 & 4.7 & 8.3 & 0.0 & 0.0 & 3.92 & 2.08 & 1.00 \\
$\mathrm{~F}$ & 0.0 & 0.0 & 4.7 & 26.6 & 31.2 & 31.1 & 6.3 & 0.0 & 3.63 & 3.43 & 1.17 \\
$\mathrm{~F}$, & 0.0 & 0.0 & 7.2 & 43.6 & 36.6 & 9.4 & 3.1 & 0.0 & 3.87 & 3.34 & 1.25 \\
$\mathrm{~S}$ & 0.0 & 0.0 & 0.0 & 2.5 & 33.6 & 37.2 & 23.2 & 3.6 & 3.36 & 3.93 & 1.47 \\
$\mathrm{~S}$ & 0.0 & 0.0 & 0.0 & 29.8 & 30.9 & 39.3 & 0.0 & 0.0 & 3.61 & 3.51 & 1.00 \\
$\mathrm{X}$ & 0.0 & 0.0 & 2.6 & 13.2 & 36.7 & 37.8 & 9.7 & 0.0 & 3.53 & 3.65 & 1.20 \\
$\mathrm{X}$ & 0.0 & 0.0 & 8.3 & 29.7 & 30.8 & 19.5 & 11.7 & 0.0 & 3.69 & 3.33 & 1.37 \\
$\mathrm{Y}$ & 0.0 & 0.0 & 0.0 & 0.0 & 38.6 & 48.2 & 13.3 & 0.0 & 3.39 & 4.00 & 1.22 \\
$\mathrm{Y}$ & 0.0 & 0.0 & 0.0 & 12.0 & 29.8 & 42.0 & 16.3 & 0.0 & 3.42 & 3.71 & 1.28 \\
\hline
\end{tabular}
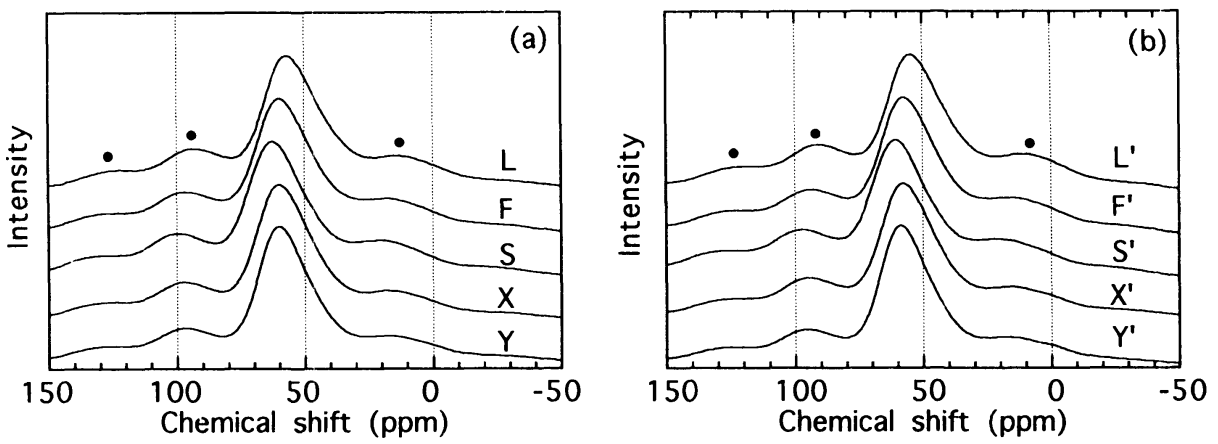

Fig. $7{ }^{27} \mathrm{Al}$ MAS NMR spectra for the $\mathrm{CaO}-\mathrm{Al}_{2} \mathrm{O}_{3}-\mathrm{SiO}_{2}$ glasses (a) and the $\mathrm{CaO}-$ $\mathrm{Al}_{2} \mathrm{O}_{3}-\mathrm{SiO}_{2}-\mathrm{CaF}_{2}$ glasses (b). ("•" denotes spinning side bands.)

the above consideration, each $\mathrm{Q}^{\mathrm{m}}(\mathrm{nAl})$ species in the glasses containing fluoride can be obtained in the same way as in the oxide glasses. Thus the ${ }^{29} \mathrm{Si}$ MAS NMR peaks of the glasses containing fluoride were separated in the manner reported by our previous study ${ }^{12)}$ and the fraction of each $\mathrm{Q}^{\mathrm{m}}(\mathrm{nAl})$ species was determined based on the peak area of each separated peak. Table 1 shows the the distribution of $\mathrm{Q}^{\mathrm{m}}(\mathrm{nAl})$ species in all glasses used in the present study. Fluoride addition caused much difference in the distribution of $\mathrm{Q}^{\mathrm{m}}(\mathrm{nAl})$ species in the glasses. However, it seemed to be difficult to describe the change in distribution of each species by the fluoride addition. Therefore we calculated the average number of bridging oxygen (Ave.m) and the average number of $\mathrm{Al}$ around a $\mathrm{SiO}_{4}$ tetrahedron in $\mathrm{Q}^{4}(\mathrm{nAl})$ and $\mathrm{Q}^{3}(\mathrm{nAl}$ ) species (Ave.4n and Ave.3n). Table 1 also shows the values of Ave.m, Ave.4n and Ave.3n and discussion of those values will be given later. .

${ }^{27}$ Al MAS NMR spectra for the glasses

Fig. 7 shows ${ }^{27} \mathrm{Al}$ MAS NMR spectra for the glasses. A mark (•), denotes spinning side bands, which appears every $38 \mathrm{ppm}$ away from a main peak around $60 \mathrm{ppm}$. The 
chemical shift of $\mathrm{Al}$ depends on the coordination number around the $\mathrm{Al}$ atom. Sixcoordinated $\mathrm{Al}$ shows a chemical shift between 20 and $-10 \mathrm{ppm}$, five-coordinated $\mathrm{Al}$ between 30 and $40 \mathrm{ppm}$ and tetrahedrally coordinated $\mathrm{Al}$ shows between 50 and 80 $\mathrm{ppm}^{13)}$. The existence of $\mathrm{six}^{-}$or five-coordinated $\mathrm{Al}$ in the glasses was not clear because of overlapping of those peak with the spinning side bands. Detection of fivecoordinated $\mathrm{Al}$ was almost impossible at the low rotating speed $(4 \mathrm{kHz})$ used in this study. A high rotating speed over $10 \mathrm{kHz}$ is needed for full detection of five-coordinated $\mathrm{Al}^{14)}$, that is, as the rotating speed at a magic angle increases, broadening of the NMR signal due to quadrapole interaction is depressed ${ }^{15)}$ and the spinning side band is kept away from the central peak. However, even at such a high speed rotation, five- or six-coordinated $\mathrm{Al}$ have been proven not to exist in calcium aluminosilicate glasses containing about $50 \mathrm{~mol} \% \mathrm{SiO}_{2}$ with an equimolar ratio of $\mathrm{CaO} / \mathrm{Al}_{2} \mathrm{O}_{3}{ }^{14)}$. Therefore most of the $\mathrm{Al}$ ions seemed to exist as tetrahedrally coordinated ones in the glasses (except for glass $\mathrm{S}^{\prime}$ ) used in the present study. Fig. 8 shows the ${ }^{27} \mathrm{Al}$ MAS NMR spectra of glasses $\mathrm{S}$ and $\mathrm{S}^{\prime}$ taken at a rotating speed of $5.8 \mathrm{kHz}$, which was the maximum limit in the apparatus used in this study. The spectrum of the glass containing $\mathrm{CaF}_{2}$ (glass $\mathrm{S}^{\prime}$ ) showed a shoulder around $30 \mathrm{ppm}$ (as indicated by an arrow), suggesting that a part of $\mathrm{Al}$ ion is five-coordinated by the addition of fluoride.

It is yet unknown how the fluoride ion is coordinated to an $\mathrm{Al}^{3+}$ ion in the glasses. However, Kohn et al. ${ }^{9)}$ described in their ${ }^{27} \mathrm{Al}$ NMR study that five- and six-coordinated aluminum fluoride complexes existed in $\mathrm{F}$-containing sodium aluminosilicate glasses. NMR signals appeared around $22 \mathrm{ppm}$ with five-coordinated species $\mathrm{AlF}_{5}{ }^{2-}$, and around $-4 \mathrm{ppm}$ with six-coordinated species $\mathrm{AlF}_{6}{ }^{3-}$. Later, Tossel $^{16)}$ reported that the five-coordinated species was expressed in the form of $\mathrm{AlO}_{2} \mathrm{~F}_{3}{ }^{2-}$ rather than $\mathrm{AlF}_{5}{ }^{2-}$.

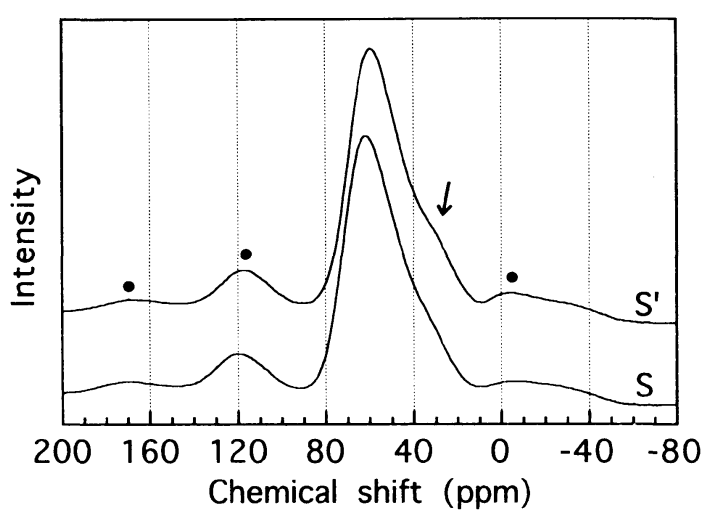

Fig. $8{ }^{27} \mathrm{Al}$ MAS NMR spectra of glasses $\mathrm{S}$ and S' taken at a rotating speed of $5.8 \mathrm{kHz}$. ("๑" denotes spinning side bands.) 

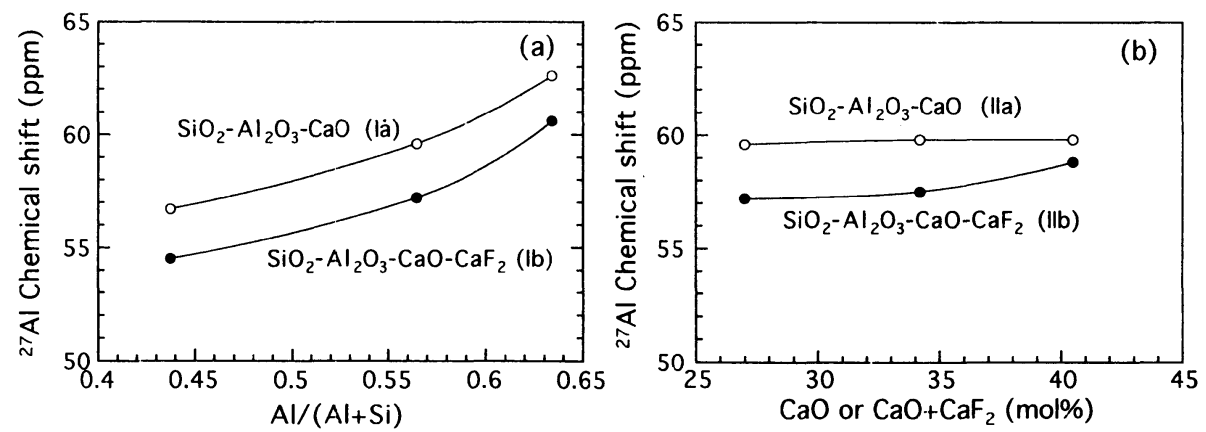

Fig. $9{ }^{27} \mathrm{Al}$ MAS NMR chemical shift of the four-coordinated Al plotted against the $\mathrm{Al} /(\mathrm{Al}+\mathrm{Si})$ ratio in series $\mathrm{I}$ a and $\mathrm{I} b$ glasses (a) and against $\mathrm{CaO}$ or $\mathrm{CaO}+\mathrm{CaF}_{2}$ content in series $\mathrm{II} \mathrm{a}$ and $\mathrm{II} \mathrm{b}$ glasses $(\mathrm{b})$.
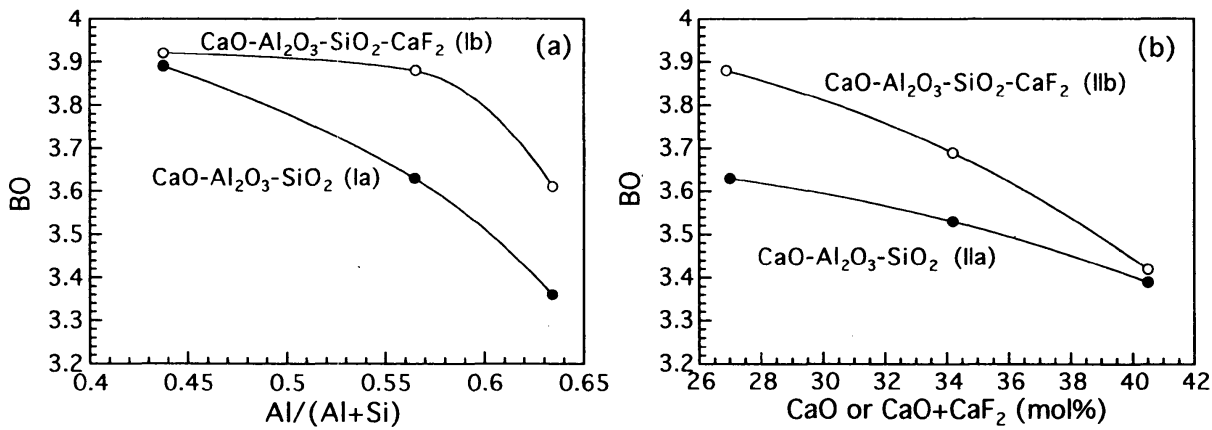

Fig. 10 The number of bridging oxygen(BO) obtained from ${ }^{29} \mathrm{Si}$ MAS NMR experiments plotted against the $\mathrm{Al} /(\mathrm{Al}+\mathrm{Si})$ ratio in series $\mathrm{I}$ a and $\mathrm{I} b$ glasses (a) and against $\mathrm{CaO}$ or $\mathrm{CaO}+\mathrm{CaF}_{2}$ content in series II a and II b glasses (b).

Fig. 9 shows the chemical shift of the four-coordinated $\mathrm{Al}$ plotted against the $\mathrm{Al} /(\mathrm{Al}+\mathrm{Si})$ ratio in series $\mathrm{I}$ a and $\mathrm{I} b$ glasses (a) and against $\mathrm{CaO}$ or $\mathrm{CaO}+$ $\mathrm{CaF}_{2}$ content in series $\mathrm{I} \mathrm{a}$ and $\Pi \mathrm{b}$ glasses (b). The ${ }^{27} \mathrm{Al}$ chemical shift increased with the $\mathrm{Al} /(\mathrm{Al}+\mathrm{Si})$ ratio in series $\mathrm{I}$ a and $\mathrm{I} b$ glasses. On the other hand, the ${ }^{27} \mathrm{Al}$ chemical shift was almost independent of the $\mathrm{CaO}$ content in series $\mathrm{II}$ a glasses and slightly increased with $\mathrm{CaO}+\mathrm{CaF}_{2}$ content in series $\mathrm{Il} \mathrm{b}$ glasses. The chemical shift was decreased by the addition of fluoride in both series of glasses and this tendency was similar to that in the ${ }^{29} \mathrm{Si}$ chemical shift.

\section{Effect of fluoride addition on $Q^{m}(n A l)$ distribution}

Fig. 10 shows the changes in the average number of bridging oxygen with $\mathrm{Al} /(\mathrm{Al}+\mathrm{Si})$ ratio in series I glasses (a) and with $\mathrm{CaO}$ content in series II glasses (b). The addition of fluoride to the aluminosilicate glasses tended to increase in the average number of bridging oxygen. This fact suggests that the role of $\mathrm{Ca}^{2+}$ as a network 

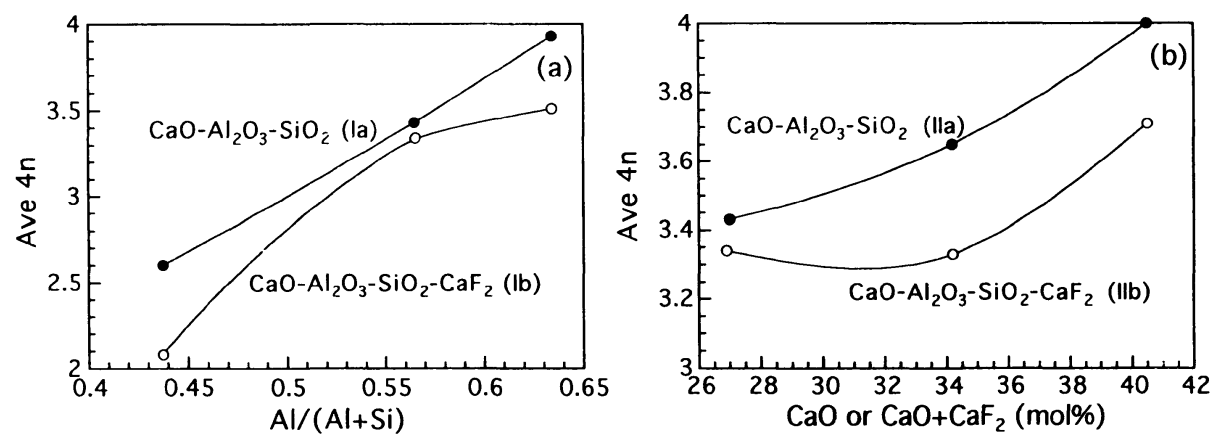

Fig. 11 The number of $\mathrm{Al}$ around a $\mathrm{SiO}_{4}$ tetrahedron in $\mathrm{Q}^{4}(\mathrm{nAl})$ species obtained from ${ }^{29} \mathrm{Si}$ MAS NMR experiments plotted against the $\mathrm{Al} /(\mathrm{Al}+\mathrm{Si})$ ratio in series $\mathrm{I}$ a and $\mathrm{I} b$ glasses (a) and against $\mathrm{CaO}$ or $\mathrm{CaO}+\mathrm{CaF}_{2}$ content in series II $a$ and II $b$ glasses ( $b)$.

modifier weakened because of bonding with fluoride. Fig. 11 shows changes in the average number of $\mathrm{Al}$ around a $\mathrm{SiO}_{4}$ tetrahedron of $\mathrm{Q}^{4}(\mathrm{nAl}$ ) species (Ave $4 \mathrm{n}$ ) with $\mathrm{Al} /$ $(\mathrm{Al}+\mathrm{Si})$ ratio in series $\mathrm{I}$ glasses (a) and with $\mathrm{CaO}$ content in series II glasses (b). The value of Ave $4 \mathrm{n}$ tended to decrease with the addition of fluoride. A part of the aluminum was no longer a network former and would act as a network modifier or be involved in a fluoride-rich phase. This caused a decrease in the ratio of $\mathrm{Al} / \mathrm{Si}$ in the glass network and resulted in the decrease of $n$ in $Q^{4}(n A l)$ species. On the other hand, with $\mathrm{Q}^{3}(\mathrm{nAl})$ species, the average number of $\mathrm{Al}$ around a $\mathrm{SiO}_{4}$ tetrahedron (Ave $3 n$ ) did not show a systematic change with fluoride addition in series I glasses and was not affected in series II glasses (Table 1).

The composition of the fluoride-rich phase was not known and its existence has not yet been confirmed experimentally. However, the phase seemed to be a solid solution of $\mathrm{CaO}, \mathrm{CaF}_{2}, \mathrm{Al}_{2} \mathrm{O}_{3}$ and $\mathrm{AlF}_{3}$ with any composition. It was reported that $\mathrm{CaF}_{2}$ was crystallized from calcium aluminosilicate glasses containing fluoride ${ }^{10)}$. This finding would offer an indirect evidence of the fluoride-rich phase in the glasses.

\section{CONCLUSION}

The effect of $\mathrm{CaF}_{2}$ addition on the structure of $\mathrm{CaO}-\mathrm{Al}_{2} \mathrm{O}_{3}-\mathrm{SiO}_{2}$ glasses was investigated with XPS and NMR analyses. The XPS spectra showed that most of the fluoride combined with $\mathrm{Ca}$ and $\mathrm{Al}$ or existed as a free ion in the glasses. The number of $\mathrm{F}$ per $\mathrm{Ca}$ atom and the fraction of free $\mathrm{F}^{-}$ion decreased with increasing $\mathrm{Al} /(\mathrm{Al}+\mathrm{Si})$ ratio in the glasses with $\mathrm{Ca} / \mathrm{Al}=0.5$. The fraction of free $\mathrm{F}^{-}$ion increased at high $\mathrm{CaO}$ content in the glasses containing about $45 \mathrm{~mol} \% \mathrm{SiO}_{2}$. Chemical shift of the fluoride-containing glasses in ${ }^{29} \mathrm{Si} \mathrm{NMR}$ and ${ }^{27} \mathrm{Al} \mathrm{NMR}$ spectra was smaller than that of the non-fluoride glasses. The addition of $\mathrm{CaF}_{2}$ caused an increase in the average number of bridging oxygen in the aluminosilicate glass network. However, the average number of $\mathrm{Al}$ around a $\mathrm{SiO}_{4}$ tetrahedron $(n)$ decreased in $\mathrm{Q}^{4}(\mathrm{nAl})$ species. 


\section{REFERENCES}

1) Kent, B. E., Lewis, B. G. and Wilson, A. D.: The properties of a glass ionomer cement, Br Dent J 135(7) : 322-326, 1973.

2) Crisp, S., Lewis, B. G. and Wilson, A. D.: Gelation of polyacrylic acid aqueous solutions and the measurement of viscosity, $J$ Dent Res 54:1173-1175, 1975.

3) Barry, T. I., Clinton, D. J. and Wilson, A. D.: The structure of a glass-ionomer cement and its relationship to the setting process, $J$ Dent Res 58(3):1072-1079, 1979.

4) Crisp, S. and Wilson, A. D.: Reaction in glass ionomer cements: I. Decomposition of the powder, $J$ Dent Res 53(6): 1408-1413, 1974.

5) Wilson, A. D., Groffman, D. M. and Kuhn, A. T.: The release of fluoride and other chemical species from a glass-ionomer cement, Biomaterials $6: 431-434,1985$.

6) Kumar, D., Ward, R. G. and Williams, D. J.: Effect of fluorides on silicate and phosphates, Discuss Farad Soc 32 : 147-154, 1961.

7) Yamane, M., Mizoguchi, K., Suginohara, Y. and Kaneko, Y.: Structural analysis for fluorosilicate glasses by X-ray photoelectron spectroscopy, Research Report of Kyushu Institute of Technology (Engineering) 51:41-48, 1985. (in Japanese)

8) Iwamoto, N. and Makino, Y.: A structural investigation of calcium fluorosilicate glasses, J Non-Cryst Solids 46: 81-94, 1981.

9) Kohn, S. C., Dupree, R., Mortuza, M. G. and Henderson, C. M. B.: NMR evidence for five- and six-coordinated aluminum fluoride complexes in $\mathrm{F}$-bearing aluminosilicate glasses, Am Mineral $76: 309-312,1991$.

10) Hill, R. G., Goat, C. and Wood, D.: Thermal analysis of a $\mathrm{SiO}_{2}-\mathrm{Al}_{2} \mathrm{O}_{3}-\mathrm{CaO}-\mathrm{CaF}_{2}$ glass, J Am Ceram Soc 75(4) : 778-785, 1992.

11) Wood, D. and Hill, R.: Structure-property relationships in ionomer glasses, Clinical Materials 7 : 301-312, 1991.

12) Maeda, T., Matsuya, S. and Ohta, M.: ${ }^{29} \mathrm{Si}$ and ${ }^{27} \mathrm{Al}$ NMR and ESCA studies on $\mathrm{SiO}_{2}-$ $\mathrm{Al}_{2} \mathrm{O}_{3}-\mathrm{CaO}$ glasses, $J$ Jpn Soc Dent Mater Dev 12(6):765-772, 1993. (in Japanese)

13) Chemical Society of Japan ed., Jikken Kagaku Kouza 4th ed. No.5 NMR, Maruzen, Tokyo, 1990 p.231 (in Japanese)

14) Sato, R. K., McMillan, P.F., Dennison, P. and Dupree, R.: A structural investigation of high alumina glasses in the $\mathrm{CaO}-\mathrm{Al}_{2} \mathrm{O}_{3}-\mathrm{SiO}_{2}$ system via Raman and magic angle spinning nuclear magnetic resonance spectroscopy, Phys Chem Glasses 32(4) : 149-156, 1991.

15) Akitt, J. W. NMR and Chemistry: An introduction to modern NMR spectroscopy, 3rd ed. Chapman \& Hall, London, 1992 pp.250-255.

16) Tossel, J.A.: Theoretical studies of the speciation of $\mathrm{Al}$ in $\mathrm{F}$-bearing aluminosilicate glasses, Am Mineral 78:16-22, 1993. 